\title{
Perbaikan Faktor Daya Menggunakan Cuk Converter pada Pengaturan Kecepatan Motor Brushless DC
}

\author{
Hadyan Perdana Putra, Heri Suryoatmojo, dan Sjamsjul Anam \\ Jurusan Teknik Elektro, Fakultas Teknologi Industri, Institut Teknologi Sepuluh Nopember (ITS) \\ Jl. Arief Rahman Hakim, Surabaya 60111 \\ E-mail: hadyanperdanaputra@gmail.com, suryomgt@ee.its.ac.id, anam@ee.its.ac.id
}

\begin{abstract}
Abstrak- Brushless DC motor (BLDC) adalah mesin listrik yang sangat serbaguna. Secara konstruksi, BLDC adalah motor sinkron dengan gulungan ketat dan magnet permanen dipasang pada rotor. Dengan tidak menggunakan sikat dan komutator, sikat kerusakan dan percikan api tidak ditemukan di motor ini dan membuat BLDC lebih efisien daripada jenis lain dari motor listrik. BLDC digunakan dalam berbagai aplikasi, seperti aplikasi rumah tangga, transportasi, aerospace, pemanasan, ventilasi, robotika, dan banyak lainnya. Dalam operasi BLDC menggunakan sumber AC, rectifier dan menghubungkan kapasitor umumnya digunakan. Dan juga, karena BLDC perlu gelombang saat persegi untuk bekerja, penggunaan inverter diperlukan. Inverter juga digunakan untuk tujuan kontrol kecepatan di kontrol kecepatan BLDC konvensional. Kontrol kecepatan konvensional yang hanya menggunakan DBR dan inverter menghasilkan harmonik yang besar yang berarti mengurangi faktor daya juga. Untuk mengatasi masalah ini, dapat digunakan DC-DC konverter antara rectifier dan inverter. Pada penelitian ini akan diteliti pengaruh mode Cuk Converter sebagai penghubung antara DBR dan inverter terhadap faktor daya sumber.
\end{abstract}

Kata Kunci - Motor Brushless DC, Cuk Converter, Power Factor Correction, Kontrol Kecepatan.

\section{PENDAHULUAN}

$\mathrm{M}$ OTOR brushless DC sangat populer untuk digunakan pada daya rendah dan menengah. Motor jenis ini memiliki banyak kelebihan, seperti tingkat efisiensinya yang tinggi, biaya pemeliharaan yang rendah, torsi tinggi dibandingkan dengan rasio berat, ranah kerja kecepatan yang luas, sangat handal, tidak bising dalam operasinya, serta usia yang lebih tahan lama [1]. Kelebihan tersebut dijadikan alasan banyaknya aplikasi motor brushless DC, seperti pada mesin cuci, pendingin ruangan, kulkas, kendaraan listrik, actuator, dan lain-lain [2].

Motor BLDC sejatinya adalah motor sinkron 3 (tiga) fasa yang terdiri dari stator dengan belitan tiga fasa dan magnet permanen pada rotornya [3], [4]. Dengan tidak adanya sikat mekanis dan komutator, kerusakan sikat akibat pengoperasian dan masalah percikan yang kerap ditemui pada motor DC konvensional tidak dimeukan di motor brushless DC. Motor ini juga disebut sebagai motor dengan komutasi elektris karena komutasi elektris berbasis sinyal sensor hall-effect untuk posisi rotor dan sensor back-emf lebih sering digunakan dibandingkan komutasi mekanis [5].

Dalam pengoperasian dengan menggunakan sumber tegangan AC satu fasa, umumnya motor brushless DC membutuhkan full-wave rectifier, kapasitor DC link, serta inverter dimana kontrol dilakukan melalui switching pada inverter menggunakan Pulse Width Modulation (PWM) [4]. Pengoperasian ini dapat menghasilkan nilai Total Harmonic Distortion (THD) dari arus sumber dan mengurangi faktor daya dari sumber AC karena pengaturan kecepatan menggunakan switching PWM pada inverter menyebabkan losses yang diakibatkan oleh frekuensi dari switching tersebut [6]. Untuk mereduksi harmonisa dan perbaikan faktor daya dapat dilakukan dengan memasang filter pasif, filter aktif, dan hybrid filter dimana aplikasi ini untuk daya yang tinggi dan instalasi sistem yang telah ada. Tetapi cara seperti ini sangat memerlukan biaya mahal dan masih ada losses lainnya. Maka ada cara lain yaitu dengan memakai konverter. Konverter yang sering digunakan untuk PFC(Power Factor Correction) yaitu Boost Converter, Buck-Boost Converter, dan Multilevel [7]. Ozturk [8] melakukan penelitian dengan Boost Converter namun memiliki kekurangan pada kontrol yang kompleks dan membutuhkan banyak sensor. Wu [9] menggunakan Cascaded Buck-Boost Converter yang menggunakan dua switch untuk PFC namun sayangnya memiliki masalah pada efisiensinya dan membutuhkan biaya yang tidak murah.

Atas pertimbangan dasar biaya dan kontrol yang kompleks, dilakukan penelitian terhadap Cuk Converter dalam kemampuannya untuk memperbaiki faktor daya sekaligus kontrol kecepatan motor brushless DC. Cuk Converter dipilih karena dapat dioperasikan dalam berbagai mode dan juga dapat digunakan untuk memperbaiki faktor daya. Pada penelitian ini, mode-mode tersebut akan dikombinasikan dengan beberapa metode kontrol berbasis PFC sehingga karakteristik dari tiap kombinasi tersebut dapat digunakan untuk kebutuhan yang lebih spesifik.

\section{DASAR TEORI}

\section{A. Motor Brushless DC}

Motor brushless DC (BLDC) adalah jenis motor DC yang tidak memiliki sikat. Dengan dihilangkannya bagian sikat dan komutator, motor ini memiliki kelebihan antara lain adalah peningkatan pada efisiensi, pengurangan kebisingan yang ditimbulkan saat berputar, perawatan yang lebih murah, serta dapat berputar dengan kecepatan tinggi karena berkurangnya gesekan dengan sikat. Sedangkan kekurangan dari motor ini adalah lebih rumit dalam kontrolnya serta harga yang lebih mahal. 
Secara konstruksi, motor brushless DC kurang lebih seperti motor AC sinkron magnet permanen, dimana belitan jangkar terletak pada stator dan rotor yang terdiri dari satu atau lebih magnet permanen, namun memiliki perbedaan pada back$E M F$. Back-EMF motor AC sinkron magnet permanen berbentuk sinusoidal sedangkan motor brushless DC berbentuk trapezoidal. Dengan back-EMF yang berbentuk trapezoidal tersebut, motor brushless DC dapat dikatakan memiliki karakteristik elektris seperti motor DC.

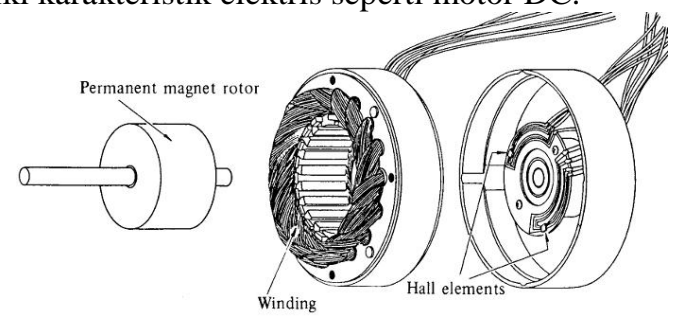

Gambar 1 Konstruksi Motor Brushless [3]

\section{B. Metode Pendeteksian Perubahan Komutasi}

Ada dua metode pendeteksian perubahan komutasi, yaitu sensorless dan menggunakan sensor. Metode sensorless adalah metode pendeteksian yang tidak membutuhkan sensor posisi mekanis rotor, dengan kata lain, metode sensorless mendeteksi aktivitias elektris dari tiap belitan yang hasilnya akan digunakan sebagai dasar perubahan komutasi. Metode sensorless dapat dilakukan dengan beberapa cara, seperti metode back-EMF terintegrasi dari terminal motor tegangan netral ke rangkaian penggeser yang tepat [10] dan pendeteksian Zero Crossing Point [11].

Adapun metode menggunakan sensor adalah metode pendeteksian dengan menggunakan sensor tambahan. Metode menggunakan sensor ini mendeteksi gerakan mekanis dari rotor dimana hasilnya akan digunakan untuk perubahan komutasi. Sensor yang sering digunakan adalah sensor halleffect. Metode ini lebih sering digunakan karena mudah dalam aplikasinya dan banyak motor yang dibuat dengan sensor halleffect didalamnya. Sensor hall-effect adalah sensor medan magnet yang dapat digunakan untuk mengetahui posisi rotor berdasarkan medan magnet yang dideteksi. Dengan menggunakan sensor ini, akan diperoleh komutasi $120^{\circ}$ antar fasa.

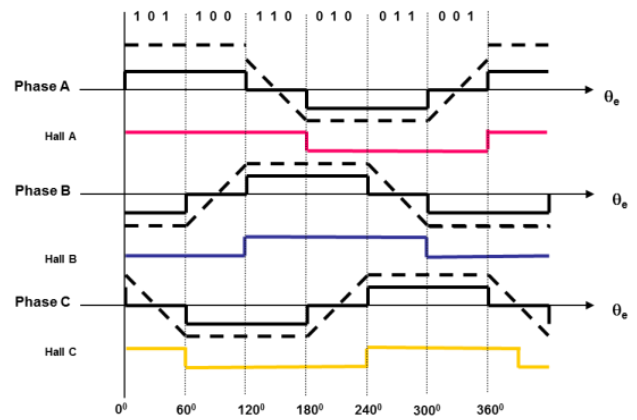

Gambar 2 Proses Komutasi berdasarkan sensor Hall-Effect

\section{Cuk Converter}

Cuk converter adalah jenis converter yang merupakan penyempurnaan dari buck-boost converter. Seperti buck-boost converter, cuk converter dapat menaikkan dan menurukan tegangan serta memiliki keluaran dengan polaritas negatif. Rangkaian cuk converter terdiri dari induktor input $\left(\mathrm{L}_{\mathrm{i}}\right)$, switch (s), kapasitor petransfer tegangan $\left(\mathrm{C}_{\mathrm{i}}\right)$, dioda (D), induktor filter $\left(\mathrm{L}_{\mathrm{o}}\right)$, dan kapasitor filter $\left(\mathrm{C}_{\mathrm{o}}\right)$. Induktor pada input bekerja sebagai filter pada suplai DC untuk mencegah harmonisa [12]. Tidak seperti converter lainnya yang menggunakan induktor sebagai perantara, cuk converter bergantung kepada kapasitor dalam transfer energi dari input ke output. Kelebihan dari converter ini adalah arus kontinyu yang pada sisi input dan outputnya, sedangkan kelemahannya adalah besarnya nilai reaktif pada komponen serta besarnya arus pada switch, dioda, dan kapasitor $\mathrm{C}_{\mathrm{i}}$.

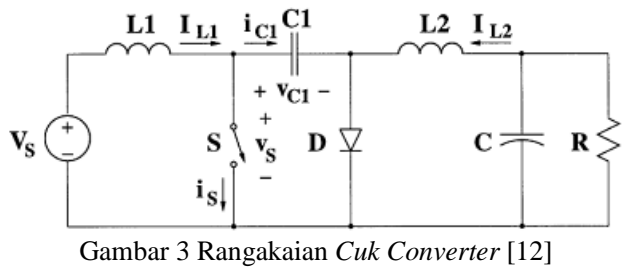

Pada keadaan switch on, switch tertutupsehingga dilewati arus, dioda tidak bekerja, dan kapasitor $\mathrm{C}_{\mathrm{i}}$ discharge oleh arus dari inductor $\mathrm{L}_{\mathrm{o}}$. Ketika switch off, switch terbuka sehingga dioda mengalirkan arus dari induktor $\mathrm{L}_{\mathrm{i}}$ dan $\mathrm{L}_{\mathrm{o}}$. Pada keadaan switch off pula kapasitor $\mathrm{C}_{\mathrm{i}}$ diisi oleh arus dari induktor $\mathrm{L}_{\mathrm{o}}$.

\section{Harmonisa dan Hubungannya dengan Power Factor}

Sistem kontrol kecepatan motor brushless DC konvensional dengan sumber AC menggunakan rectifier dan inverter tiga fasa menghasilkan harmonisa besar pada sumber [14]. Fenomena harmonisa ini, khususnya pada listrik AC, berhubungan dengan berkurangnya nilai power factor. Hubungan antara harmonisa dengan power factor dapat didefinisikan dengan rumus:

$$
P F=\cos \left(\delta_{1}-\theta_{1}\right)
$$

Dimana $\delta_{1}$ adalah sudut dari gelombang arus dan $\theta_{1}$ adalah sudut dari gelomnbang tegangan. Rumus dasar tersebut tidak dapat digunakan untuk beban no linier karena beban linier memliki faktor distorsi, yakni faktor harmonisa yang menyebabkan power factor terdistorsi. Adanya harmonisa dari arus dan tegangan pada sumber akan menghasilkan faktor distorsi (distortion factor atau DF).

$$
D F=\frac{1}{\sqrt{1+(T H D)^{2}}}
$$

Besarnya nilai distortion factor ini akan mempengaruhi nilai power factor dari sistem. Pengaruh ini dapat dituliskan dengan persamaan

$$
T P F=D P F \times D F
$$

Dimana TPF merupakan nilai faktor daya nyata yang terjadi karena adanya faktor distorsi harmonisa sedangkan DPF adalah Displacement Power Factor, yang merupakan nilai faktor daya tanpa memperhitungkan harmonisa.

\section{PERANCANGAN Sistem DeteKsi KerusaKan}

\section{A. Konfigurasi Sistem}

Sistem kontrol yang digunakan pada penelitian ini secara umum dengan menggunakan sumber AC satu fasa, rectifier satu fasa, cuk converter, inverter tiga fasa, motor BLDC yang mengopel beban, serta rangkaian kontrol. Sistem keseluruhan adalah sebagai berikut 


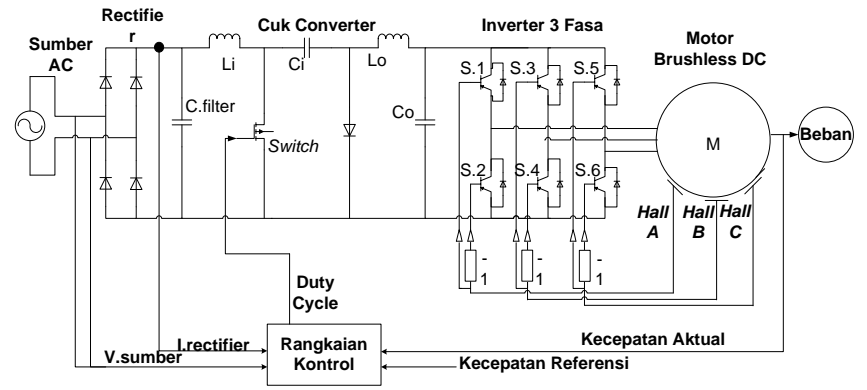

Gambar 4 Sistem Kontrol BLDC secara Keseluruhan

Pada skema konvensional dimana sumber satu fasa AC disearahkan dengan rectifier, kemudian hasil penyearahan masuk ke VSI dengan berbasis kontrol dari sinyal sensor halleffect sehingga switch dapat open dan close sesuai dengan posisi rotor dan untuk kontrol kecepatannya hanya melalui PWM yang tersambung dengan sinyal hall-effect tadi sebelum masuk ke switch VSI, kontrol kecepatan yang diperoleh dari skema sangat baik namun harmonisa yang dihasilkan besar dan berkurangnya nilai faktor daya pada sumber AC satu fasa. Untuk memperbaiki faktor daya, cuk converter dipasang diantara antara filter rectifier dengan VSI. Cuk converter disini akan bekerja sebagai instrumen untuk menjaga nilai faktor daya tetap di nilai normal serta mengurangi harmonisa hasil dari penyearahan dan switching pada VSI, dapat dikatakan fungsi cuk converter mirip seperti regulator tegangan dan arus.

\section{B. Permodelan BLDC}

Motor yang digunakan dalam tugas akhir ini adalah motor brushless DC keluaran MOOG, seri BN42-53IP-03. Motor ini memiliki daya sebesar 874 Watt.

Tabel 1

Tabel Parameter Motor MOOG Seri BN42-53IP-03

\begin{tabular}{lc}
\hline \hline Parameter & Nilai \\
\hline Rated Power & $874 \mathrm{Watt}$ \\
Rated Speed & $2820 \mathrm{rpm}$ \\
Rated Torque & $2.9588 \mathrm{Nm}$ \\
Resistance (phase-phase) & $0,408 \Omega$ \\
Inductance (phase-phase) & $1.71 \mathrm{mH}$ \\
Speed Constant $(\mathrm{krpm} / \mathrm{V})$ & 29.239 \\
Torque Constant $(\mathrm{Nm} / \mathrm{A})$ & 0.3269 \\
No. of Poles & 8 \\
Moment of Inertia & $0,4939 \times 10^{-3} \mathrm{~kg} \cdot \mathrm{m}^{2}$ \\
No Load Speed & $2920 \mathrm{rpm}$ \\
No Load Current & $0.7 \mathrm{~A}$ \\
\hline \hline
\end{tabular}

\section{Perancangan Cuk Converter dan Filter}

Perancangan cuk converter dan filter ini bertujuan untuk menyesuaikan nilai dari tiap komponen agar sesuai dengan kebutuhan penelitian. Nilai komponen dirancang berdasarkan sumber listrik dan motor yang digunakan.

Cuk converter menggunakan sumber satu fasa $220 \mathrm{~V}$ yang disearahkan oleh diode bridge rectifier (DBR) yang setelahnya diberi kapasitor sebagai filter tegangan. Karena tegangan dan arus hasil penyearahan dan filter tidak berbentuk DC murni, maka digunakan nilai rata-rata.

Pada penelitian ini, dibatasi tegangan input pada tegangan rms sumber minimal adalah $200 \mathrm{~V}$ dengan nilai maksimalnya adalah $240 \mathrm{~V}$.

\begin{tabular}{lc}
\multicolumn{2}{c}{ Tabel Rating Cuk Converter } \\
\hline \hline Vrms.max & $240 \mathrm{~V}$ \\
Vrms.min & $200 \mathrm{~V}$ \\
Vp.max & $339.14 \mathrm{~V}$ \\
Vp.min & $282.84 \mathrm{~V}$ \\
Vavg.max & $216 \mathrm{~V}$ \\
Vavg.min & $180 \mathrm{~V}$ \\
Vout.optimal & $100 \mathrm{~V}$ \\
Vout.max & $110 \mathrm{~V}$ \\
Vout.min & $10 \mathrm{~V}$ \\
Pmax & $900 \mathrm{Watt}$ \\
Pmin & $10 \mathrm{Watt}$ \\
Frekuensi Switching (f) & $20.000 \mathrm{~Hz}$ \\
\hline \hline
\end{tabular}

Dua mode converter berdasarkan switching akan diteliti pada penelitian ini. Mode tersebut adalah CCM dan DCM pada $\mathrm{L}_{\mathrm{o}}$. Dua mode ini dibandingkan karena berdasarkan [13], mode ini adalah yang paling baik dan hasilnya kurang lebih sama. Tujuan dengan membandingkan mode ini adalah untuk mengetahui mode mana yang paling baik untuk daya maksimal 900 watt.

Ada 5 komponen yang dicari nilainya, yaitu $\mathrm{Li}, \mathrm{Lo}, \mathrm{Ci}, \mathrm{Co}$, dan Cfilter. Nilai Li diperoleh dengan persamaan

$$
L_{i}=\frac{V_{\text {avg.min }}{ }^{2} \cdot V_{\text {out.max }}}{\eta_{1} \cdot P_{\text {max }} \cdot f \cdot\left(V_{\text {p.min }}+V_{\text {o.max }}\right)}
$$

Untuk Lo, karena ada 2 mode yang akan digunakan yaitu CCM dan DCM pada Lo, maka ada 2 nilai Lo yang digunakan. Untuk Lo CCM diperoleh melalui

$$
L_{\text {o.ccm }}=\frac{V_{\text {out.max }}{ }^{2} \cdot V_{\text {avg.min }}}{\eta_{2} \cdot \sqrt{2} \cdot \mathrm{P}_{\text {max }} \cdot f \cdot\left(V_{\text {p.min }}+V_{\text {o.max }}\right)}
$$

Sedangkan DCM dicari diantara hasil 2 persamaan, dimana digunakan nilai yang terendah

$$
\begin{aligned}
& L_{\text {o.dcm } 1}=\frac{V_{\text {out.max }}{ }^{2} \cdot V_{\text {avg.min }}}{\eta_{\text {crit }} \cdot \sqrt{2} \cdot \mathrm{P}_{\text {max }} \cdot f \cdot\left(V_{\text {p.min }}+V_{\text {o.max }}\right)} \\
& L_{\text {o.dcm } 2}=\frac{V_{\text {out.min }}{ }^{2} \cdot V_{\text {avg.min }}}{\eta_{\text {crit }} \cdot \sqrt{2} \cdot \mathrm{P}_{\text {min }} \cdot f \cdot\left(V_{\text {p.min }}+V_{\text {o.min }}\right)} \\
& \text { Untuk Ci diperoleh dengan } \\
& C_{i}=\frac{P_{\text {max }}}{\eta_{3} \cdot\left(\mathrm{V}_{\text {o.max }}+V_{\text {p.max }}\right)^{2} \cdot f}
\end{aligned}
$$

Lo dapat diperoleh dengan rumus, dimana digunakan hasil yang tertinggi sebagai batas minimum

$$
\begin{aligned}
C_{o .1} & =\frac{P_{\text {max }}}{2 \cdot \pi \cdot f \cdot \eta_{4} \cdot \mathrm{V}_{o . \max }{ }^{2}} \\
C_{o .2} & =\frac{P_{\text {min }}}{2 \cdot \pi \cdot f \cdot \eta_{4} \cdot \mathrm{V}_{o . m i n}{ }^{2}}
\end{aligned}
$$

Dan Cfilter dengan persamaan

$$
C_{\text {filter }}=\frac{P_{\text {max }} \sqrt{2}}{V_{s} \cdot \omega_{L} \cdot V_{m}} \tan \left(1^{\circ}\right)
$$

Dengan menggunakan parameter pada Tabel 2, diperoleh nilai komponen sebesar 4.6 mH untuk Li, 2.2 Mh untuk Lo CCM dan $20 \mu \mathrm{H}$ untuk DCM, $3 \mu \mathrm{F}$ untuk $\mathrm{Ci}, 4 \mathrm{mF}$ untuk Co, dan 1 $\mu$ Funtuk Cfilter.

\section{D.Metode Kontrol dengan Average Current Control}

Rangkaian kontrol kecepatan didasarkan pada saat rangkaian kontrol PFC rata [13]. Sinyal referensi adalah referensi kecepatan. referensi kecepatan akan menurun umpan 
balik negatif pertama, kecepatan yang sebenarnya. PI controller digunakan untuk menstabilkan kecepatan. Kemudian, sinyal error stabil dikalikan dengan nilai absolut dari sumber tegangan yang dibagi dengan nilai puncak tegangan yaitu $311 \mathrm{~V}$. Tujuan dari perkalian adalah untuk mendapatkan sinyal sinusoidal mutlak dalam sinyal kontrol. Sinusoidal sinyal menurun dengan umpan balik negatif kedua, rectifier saat ini. PI controller digunakan kembali untuk menstabilkan kesalahan dan kemudian komparator akan membandingkan PI sinyal controller dengan sinyal gigi gergaji.

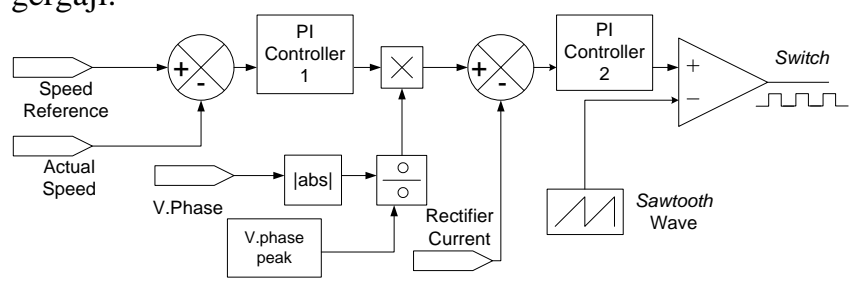

Gambar 5 Rangkaian Kontrol dengan Metode Average Current Control

\section{E. Metode Kontrol dengan Metode Histeresis}

Seperti metode average current control, pada metode ini akan digunakan kecepatan sebagai referensi dari kontrol atau biasa disebut set point. Selanjutnya melalui operasi pengurangan, dicari error dari kecepatan referensi. Kecepatan referensi tersebut dikurangi oleh nilai kecepatan aktual yang dideteksi oleh sensor kecepatan, atau dapat dikatakan, kecepatan aktual adalah umpan balik negatif. Selanjutnya, nilai error yang telah diperoleh akan diproses oleh kontroler PI. Hasil dari kontroler PI kemudian dikalikan oleh hasil sensor tegangan sumber yang telah diabsolutkan dan dibagi oleh 311, sama seperti metode sebelumnya, yang bertujuan agar sinyal berbentuk sinusoidal yang disearahkan. Gelombang tersebut kemudian masuk ke komparator dimana akan dibandingkan dengan gelombang arus rectifier dan hasil komparator kemudian dijadikan acuan untuk switching pada cuk converter.

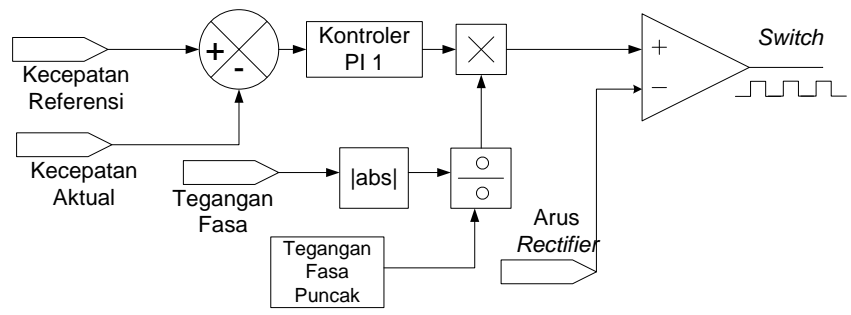

Gambar 6 Rangkaian Kontrol dengan Metode Histeresis

\section{HASIL SIMULASI DAN ANALISA}

Terdapat empat kombinasi antara dua mode dengan dua metode yang diuji. Dilakukan tiga uji pada simulasi, yaitu uji respon motor terhadap perubahan kecepatan, uji respon motor terhadap perubahan torsi, dan uji nilai THD dan PF pada kecepatan yang diuji.

Pada uji kecepatan respon terhadap perubahan referensi kecepatan, torsi beban pada nilai $2.9588 \mathrm{Nm}$ dan tegangan input sebesar $220 \mathrm{~V}$ AC rms. Berkebalikan dengan uji terhadap perubahan referensi kecepatan, uji respon motor terhadap perubahan torsi menggunakan torsi yang berubah namun kecepatan tetap pada nilai $2500 \mathrm{rpm}$ dan tegangan sebesar $220 \mathrm{~V}$ AC rms. Untuk uji nilai THD dan PF, digunakan 10 nilai kecepatan dimulai dari $250 \mathrm{rpm}$ hingga $2500 \mathrm{rpm}$ dengan jarak antara kecepatan uji sebesar $250 \mathrm{rpm}$ dan akan dibandingkan dengan nilai THD dan PF pada kecepatan 2500 rpm tanpa cuk converter.

Tabel 3

Keadaan Steady State Sumber AC pada Kontrol Kecepatan tanpa Cuk

\begin{tabular}{ll}
\multicolumn{2}{c}{ Converter pada kecepatan $2500 \mathrm{rpm}$} \\
\hline \hline THD Arus (\%) & 74.075 \\
DF & 0.80619 \\
DPF & 0.80355 \\
TPF & 0.64782 \\
\hline \hline
\end{tabular}

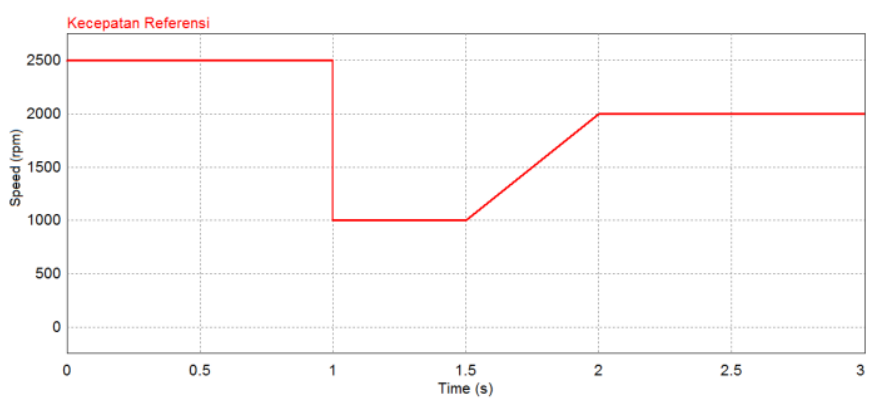

Gambar 7 Kurva Uji Kontrol Kecepatan Terhadap Perubahan Kecepatan Referensi

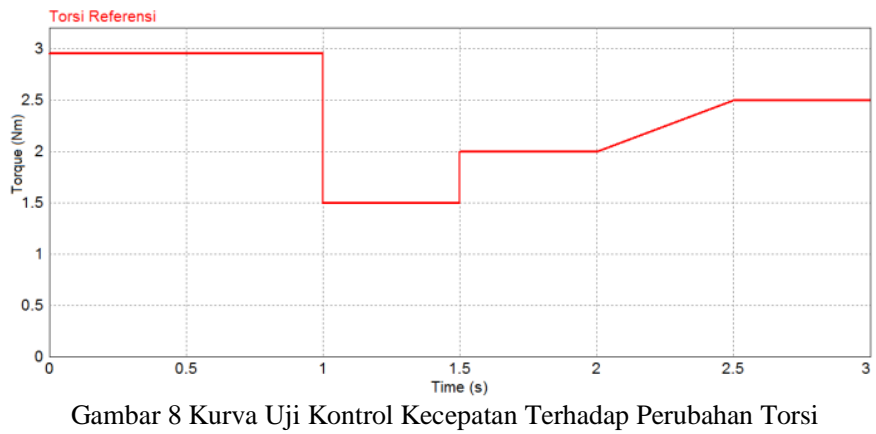

\section{A. Mode CCM dengan Metode Average Current Control}

Hasil kontrol kecepatan dengan kombinasi ini bekerja sangat baik. Respon menuju nilai $2500 \mathrm{rpm}$ dari keadaan diam sekitar 0.3 detik dan responnya ketika diturunkan ke $1000 \mathrm{rpm}$ dari 2500 rpm pun cepat meskipun kecepatan sedikit dibawah referensi ketika kecepatan dinaikkan perlahan. Hasil uji perubahan torsi pun menunjukkan respon yang cepat namun lonjakan kecepatannya cukup besar.

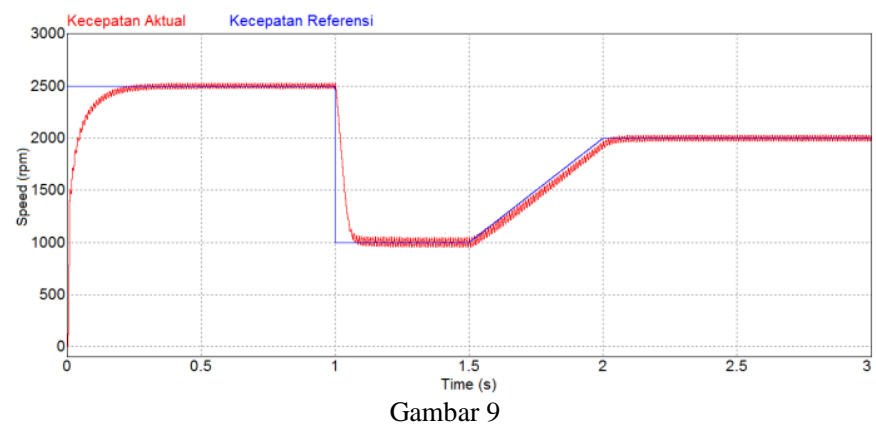

Kurva kecepatan aktual (merah) Mode CCM dengan Metode Average Current Control terhadap Kecepatan Referensi (biru) 


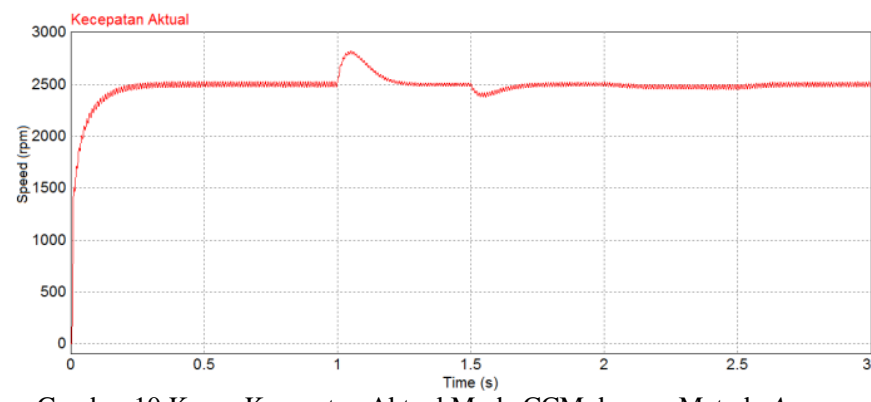

Gambar 10 Kurva Kecepatan Aktual Mode CCM dengan Metode Average Current Control pada Saat Torsi Diubah

Untuk uji THD dan PF, nilai THD tertinggi sebesar 31.1\% pada kecepatan uji rendah dan THD terendah senilai $1.967 \%$ pada kecepatan uji tertinggi. Nilai PF berkebalikan dengan THD dimana pada $250 \mathrm{rpm}$ nilainya 0.95405 dan pada 2500rpm sebesar 0.99976 .

Tabel 4

Nilai THD arus, DF, DPF, dan TPF dari Mode CCM dengan Metode Average

\begin{tabular}{cccccc}
\hline \multicolumn{5}{c}{ Current Control } \\
No. & $\begin{array}{c}\text { Speed } \\
(\mathrm{rpm})\end{array}$ & $\begin{array}{c}\text { THD } \\
(\%)\end{array}$ & DF & DPF & TPF \\
\hline 1 & 250 & 31.108 & 0.95487 & 0.99915 & 0.95405 \\
2 & 500 & 16.805 & 0.98617 & 0.99782 & 0.98402 \\
3 & 750 & 10.247 & 0.99479 & 0.99930 & 0.99409 \\
4 & 1000 & 6.997 & 0.99756 & 0.99976 & 0.99732 \\
5 & 1250 & 5.266 & 0.99862 & 0.99992 & 0.99854 \\
6 & 1500 & 3.924 & 0.99923 & 0.99995 & 0.99918 \\
7 & 1750 & 3.128 & 0.99951 & 0.99995 & 0.99946 \\
8 & 2000 & 2.620 & 0.99966 & 0.99995 & 0.99961 \\
9 & 2250 & 2.285 & 0.99974 & 0.99995 & 0.99969 \\
10 & 2500 & 1.967 & 0.99981 & 0.99995 & 0.99976 \\
\hline \hline
\end{tabular}

B. Mode DCM pada Lo dengan Metode Average Current Control

Performa mode dalam kontrol kecepatan dibawah performa mode CCM dengan metode yang sama. Waktu yang dibutuhkan untuk mencapai keadaan steady state lebih banyak, error kecepatan lebih besar, serta lonjakan kecepatan ketika terjadi perubahan torsi juga lebih besar. Nilai maksimum THD dan minimum TPF pada mode ini juga tidak sebaik mode CCM dengan metode yang sama. Namun mulai kecepatan 500 rpm, nilai THD jauh lebih kecil dan berdampak pada nilai TPF yang lebih baik pula.

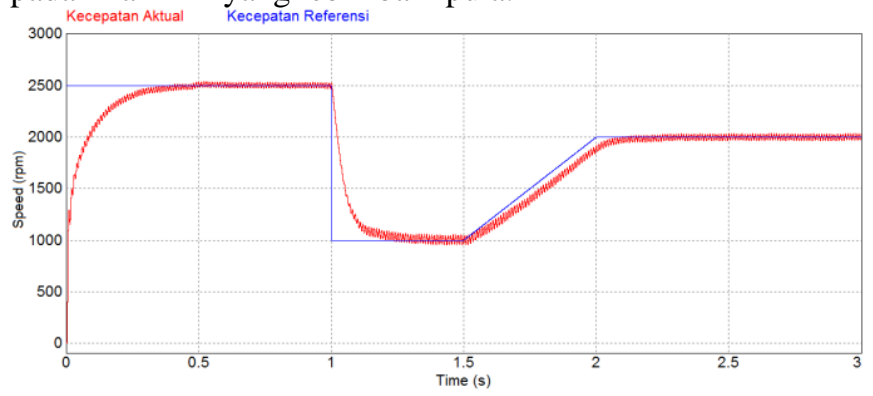

Gambar 11 Kurva kecepatan aktual (merah) Mode DCM pada $\mathrm{L}_{\mathrm{o}}$ dengan Metode Average Current Control terhadap Kecepatan Referensi (biru)

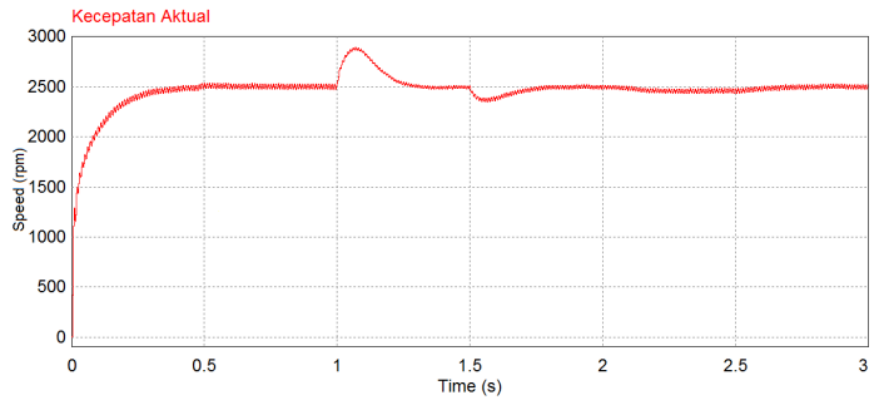

Gambar 12 Kurva Kecepatan Aktual Mode DCM pada $\mathrm{L}_{\mathrm{o}}$ dengan Metode Average Current Control pada Saat Torsi Diubah

Tabel 5

Nilai THD arus, DF, DPF, dan TPF dari Mode DCM pada Lo dengan Metode Average Current Control

\begin{tabular}{crrrrr}
\hline \hline No. & $\begin{array}{c}\text { Speed } \\
(\mathrm{rpm})\end{array}$ & \multicolumn{1}{c}{$\begin{array}{c}\text { THD } \\
(\%)\end{array}$} & \multicolumn{1}{c}{ DF } & DPF & TPF \\
\hline 1 & 250 & 33.170 & 0.94915 & 0.99698 & 0.94628 \\
2 & 500 & 12.076 & 0.99279 & 0.99988 & 0.99267 \\
3 & 750 & 7.041 & 0.99753 & 0.99998 & 0.99751 \\
4 & 1000 & 4.494 & 0.99899 & 0.99998 & 0.99897 \\
5 & 1250 & 3.475 & 0.9994 & 0.99999 & 0.99939 \\
6 & 1500 & 2.286 & 0.99974 & 0.99999 & 0.99973 \\
7 & 1750 & 1.970 & 0.99981 & 0.99999 & 0.9998 \\
8 & 2000 & 1.645 & 0.99986 & 0.99999 & 0.99985 \\
9 & 2250 & 1.408 & 0.9999 & 0.99999 & 0.99989 \\
10 & 2500 & 1.262 & 0.99992 & 0.99999 & 0.99991 \\
\hline \hline
\end{tabular}

\section{Mode CCM dengan Metode Histeresis}

Respon motor yang ditunjukkan oleh hasil simulasi pada mode CCM dengan metode histeresis ini sangat cepat. Bisa dilihat ketika awal simulasi, motor dengan cepat mencapai kecepatan 2500 rpm dari keadaan diam, lebih cepat dari mode yang sama dengan metode sebelumnya. Motor dapat mengikuti referensi yang naik perlahan dengan baik pula. namun ketika kecepatan diubah dari 2500 rpm ke $1000 \mathrm{rpm}$ kecepatan merosot ke nilai dibawah refrensinya sebelum mencapai keadaan tunak. Ketika diberikan perubahan torsi, kecepatan responnya kurang lebih sama seperti mode CCM dengan metode sebelumnya tetapi lonjakan kecepatan jauh lebih kecil. Sayangnya, performanya untuk mengurangi THD dan memperbaiki PF dibawah mode CCM dengan metode sebelumnya. Nilai THD pada kecepatan $250 \mathrm{rpm}$ lebih tinggi, begitu pula THD pada kecepatan $2500 \mathrm{rpm}$. Nilai PF pun maksimum dan minimum juga lebih rendah.

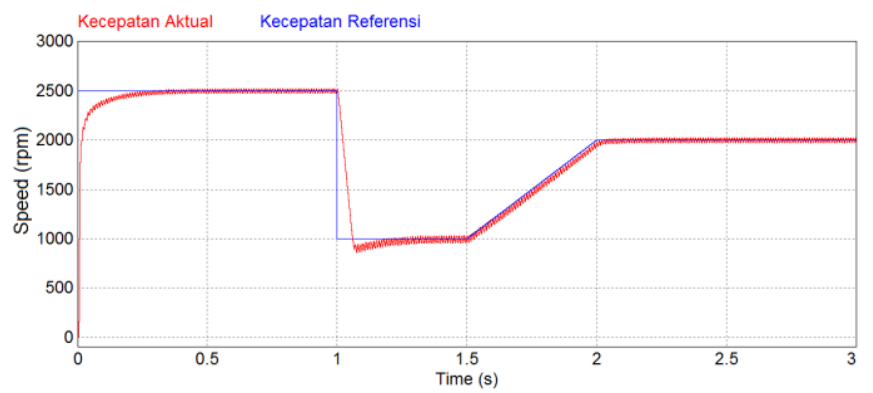

Gambar 13 Kurva kecepatan aktual (merah) Mode CCM dengan Metode Histeresis terhadap Kecepatan Referensi (biru) 


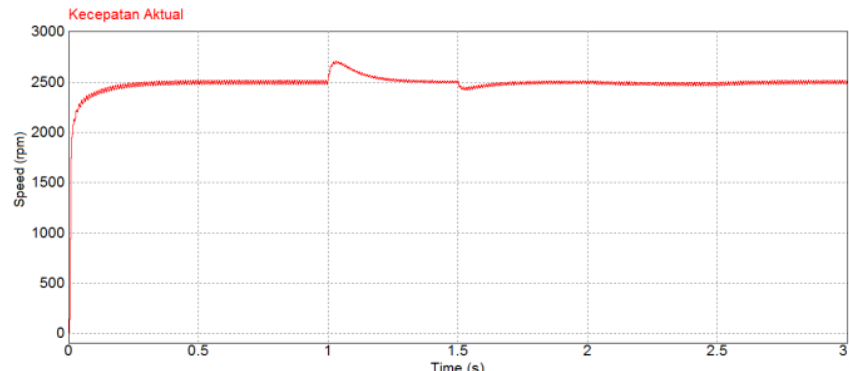

Gambar 14 Kurva Kecepatan Aktual Mode CCM dengan Metode Histeresis pada Saat Torsi Diubah

Tabel 6

Nilai THD arus, DF, DPF, dan TPF dari Mode CCM dengan Metode Histeresis

\begin{tabular}{crrcrr}
\hline \hline No. & $\begin{array}{r}\text { Speed } \\
(\mathrm{rpm})\end{array}$ & $\begin{array}{c}\text { THD } \\
(\%)\end{array}$ & DF & DPF & \multicolumn{1}{c}{ TPF } \\
\hline 1 & 250 & 31.820 & 0.95292 & 0.99452 & 0.9477 \\
2 & 500 & 22.675 & 0.97524 & 0.9934 & 0.96881 \\
3 & 750 & 13.814 & 0.99059 & 0.99685 & 0.98747 \\
4 & 1000 & 9.505 & 0.99551 & 0.99898 & 0.9945 \\
5 & 1250 & 6.683 & 0.99777 & 0.99957 & 0.99735 \\
6 & 1500 & 4.986 & 0.99876 & 0.99977 & 0.99853 \\
7 & 1750 & 3.815 & 0.99927 & 0.99988 & 0.99915 \\
8 & 2000 & 3.211 & 0.99948 & 0.99993 & 0.99941 \\
9 & 2250 & 2.614 & 0.99966 & 0.99996 & 0.99962 \\
10 & 2500 & 2.286 & 0.99974 & 0.99997 & 0.99971 \\
\hline \hline
\end{tabular}

D. Mode DCM pada Lo dengan Metode Histeresis

Hasil terhadap referensi kecepatan yang beragam menunjukkan bahwa motor mengikuti referensi dengan cukup baik. Dibandingkan dengan mode yang sama dengan metode sebelumnya, performa kontrol kecepatan masih lebih baik pada sisi kecepatan respon dan error kecepatan. Namun bila dibandingkan dengan mode CCM pada metode yang sama, performanya kalah bagus, terlebih pada kecepatan respon dan error ketika kecepatan dinaikkan perlahan. Respon yang lebih lama juga ditunjukkan ketika terjadi perubahan torsi.

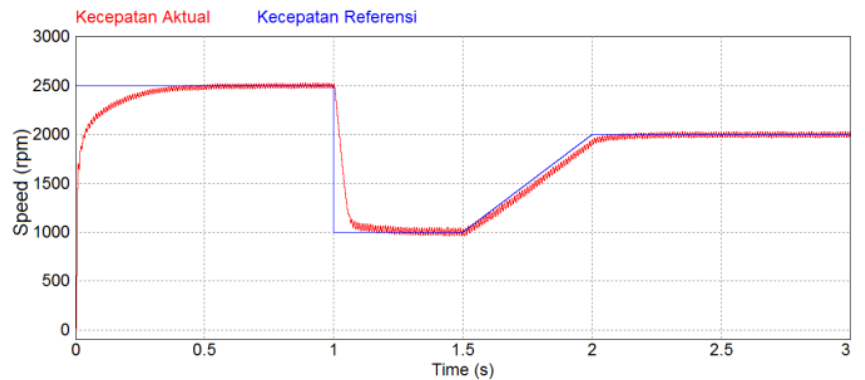

Gambar 15 Kurva kecepatan aktual (merah) Mode DCM pada $\mathrm{L}_{\mathrm{o}}$ dengan Metode Histeresis terhadap Kecepatan Referensi (biru)

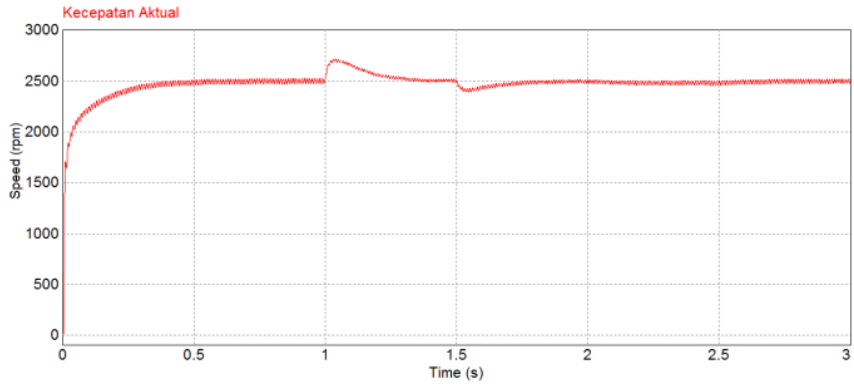

Gambar 16 Kurva Kecepatan Aktual Mode DCM pada $\mathrm{L}_{\mathrm{o}}$ dengan Metode Histeresis pada Saat Torsi Diubah

Uji THD dan TPF pada mode DCM pada Lo dengan metode histeresis menunjukkan hasil yang sangat baik. Nilai tertinggi THD yakni sebesar $20.767 \%$ ini jauh lebih rendah dibandingkan kombinasi lainnya dan juga nilai terendah THD pada $2500 \mathrm{rpm}$ juga sangat baik yaitu sebesar $1.428 \%$ meskipun $1.66 \%$ lebih besar dibandingkan mode yang sama dengan metode yang berbeda.

Tabel 7

Nilai THD arus, DF, DPF, dan TPF dari Mode DCM pada $\mathrm{L}_{\mathrm{o}}$ dengan Metode Histeresis

\begin{tabular}{crrccc}
\hline \hline No. & $\begin{array}{c}\text { Speed } \\
(\mathrm{rpm})\end{array}$ & $\begin{array}{c}\text { THD } \\
(\%)\end{array}$ & DF & DPF & TPF \\
\hline 1 & 250 & 20.767 & 0.97911 & 0.98977 & 0.96909 \\
2 & 500 & 15.67 & 0.98794 & 0.99710 & 0.98508 \\
3 & 750 & 7.834 & 0.99695 & 0.99954 & 0.99649 \\
4 & 1000 & 5.440 & 0.99852 & 0.99983 & 0.99835 \\
5 & 1250 & 3.888 & 0.99925 & 0.99915 & 0.99840 \\
6 & 1500 & 3.142 & 0.99951 & 0.99995 & 0.99946 \\
7 & 1750 & 2.429 & 0.99971 & 0.99997 & 0.99968 \\
8 & 2000 & 2.021 & 0.99980 & 0.99998 & 0.99978 \\
9 & 2250 & 1.716 & 0.99985 & 0.99998 & 0.99983 \\
10 & 2500 & 1.428 & 0.99990 & 0.99999 & 0.99989 \\
\hline \hline
\end{tabular}

\section{KESIMPULAN}

1. Cuk Converter yang diberikan kontrol power factor correction mampu mengurangi harmonisa hingga ke titik $1.26 \%$ yang sebelumnya $74.08 \%$ dan memperbaiki faktor daya hingga mencapai nilai 0.99984 yang sebelumnya hanya 0.64782 .

2. Kemampuan untuk mengurangi harmonisa dan perbaikan faktor daya dari Cuk Converter dengan mode DCM pada $\mathrm{L}_{\mathrm{o}}$ lebih baik dibandingkan Cuk Converter mode CCM. Mode DCM pada $\mathrm{L}_{\mathrm{o}}$ juga sedikit lebih murah dalam pembuatannya karena nilai induktor $\mathrm{L}_{\mathrm{o}}$ yang lebih kecil. Namun dalam kecepatan respon dalam kontrol kecepatan dan kestabilan pada saat perubahan torsi mode CCM lebih unggul dari mode DCM pada $\mathrm{L}_{\mathrm{o}}$.

3. Kontrol kecepatan berbasis perbaikan faktor daya dengan metode average current control lebih unggul dibandingkan metode histeresis pada sisi kontrol kecepatan. Di sisi mitigasi harmonisa dan perbaikan faktor daya pun secara keseluruhan masih unggul tetapi untuk mode DCM pada $\mathrm{L}_{\mathrm{o}}$, metode histeresis dapat dikatakan sedikit lebih baik karena nilai THD pada kecepatan uji terendah $(250 \mathrm{rpm})$ 
yang jauh lebih kecil. Selain itu, metode histeresis juga lebih murah dalam implementasinya karena tidak menggunakan gelombang sawtooth dan hanya butuh satu kontroler PI.

\section{DAFTAR PUSTAKA}

[1] Anoop Mathew Korula, Sudhanshu Tripathi , "Reduction of Harmonics to Improve Performance of Permanent Magnet Brushless DC Motor Drive Using Cuk Converter", ISSN ,vol-2, Issue-6, June 2013

[2] Padmaraja Yedamale, "Brushless DC (BLDC) Motor Fundamentals" Microchip technology ,2003.

[3] T. Kenjo and S. Nagamori, Permanent Magnet Brushless DC Motors. Oxford, U.K.: Clarendon Press, 1985.

[4] J. R. Handershot and T. J. E Miller, Design of Brushless Permanent Magnet Motors. Oxford, U.K.: Clarendon Press, 2010.

[5] T. J. Sokira and W. Jaffe, Brushless DC Motors: Electronics Commutation and Controls. Blue Ridge Summit, PA, USA: Tab Books, 1989.

[6] B. Singh and V. Bist, 'Power quality improvement in a zeta converter for brushless DC motor drives' IET Sci. Meas. Technol., Vol. 9, Iss. 3, pp. 351-361, 2015.

[7] Singh, B., Singh, S., Chandra, A., Al-Haddad, K.: 'Comprehensive study of single-phase AC-DC power factor corrected converters with high-frequency isolation', IEEE Trans. Ind. Inf., vol. 7, no. 4, pp. 540-556, 2011

[8] S. B. Ozturk, O. Yang, and H. A. Toliyat, "Power factor correction of direct torque controlled brushless DC motor drive" in Proc. 42nd IEEE IAS Annu. Meeting, Sep. 23-27, 2007, pp. 297-304.

[9] C. H. Wu and Y. Y. Tzou, "Digital control strategy for efficiency optimization of a BLDC motor driver with VOPFC," in Proc. IEEE Energy Convers. Congr. Expo., Sep. 20-24, 2009, pp. 2528 2534.

[10] J. Shao, D. Nolan , M. Teissier, and D. Swanson, "A Novel Microcontroller based sensorless brushless DC (BLDC) motor drive for automotive fuel pumps", IEEE Trans. Ind. Appl., vol 39, no. 6, pp. 1730-1740, Nov./Dec. 2003

[11] R. C. Becerra, T. M. Jahns, and M. ehsani, "four-quadrant sensorless brushless ECM drive,"in Proc. APEC'91, 1991, pp. 202-209

[12] D. W. Hart, "Power Electronics". New York, USA. McGraw-Hill, 2011

[13] V. Bist and B. Singh, 'PFC Cuk Converter-Fed BLDC Drive', IEEE Transaction on Power Electronics, Vol. 30 no.2, February 2015.

[14] R. G. Ellis, 'Power System Harmonics - A Reference Guide to Cause, Effects, and Corrective Measures', Cambridge, Canada, Rockwell Automation. 2001 